\title{
New dinocyst taxa from the Eocene of the North Sea
}

\author{
J. P. BUJAK \\ The Lexis Group, 9 Albion Avenue, Blackpool, Lancashire FY3 8NA, UK.
}

\begin{abstract}
Dinoflagellate cysts (dinocysts) are abundant in the Eocene of the North Sea and provide a high-resolution biostratigraphic zonation. Twelve species are erected to accommodate zonal markers that have not been previously described. These are Areosphaeridium ebdonii, Areosphaeridium michoudii, Cerebrocysta magna, Diphyes brevispinum, Diphyes pseudoficusoides, Hystrichosphaeropsis costae, Hystrichostrogylon clausenii, Membranilarnacia compressa, Phthanoperidinium clithridium, Phthanoperidinium distinctum, Phthanoperidinium powellii and Phthanoperidinium regalis. J. Micropalaeontol. 13(2): 119-131, December 1994.
\end{abstract}

\section{INTRODUCTION}

Bujak \& Mudge (1994) defined eight dinocyst zones and 23 subzones for the Eocene of the North Sea based on last occurrence or abundance events (Fig. 1), which were observed in more than 150 wells examined from Quadrant 3 in the north to Quadrants 21 and 22 in the south. Many of the zonal markers also occur in northwest European stratotypes and reference sections, permitting correlation with standard nannoplankton (NP) zonal assignments made for these sections, of significance because few Eocene NP index species occur in North Sea wells.

Mudge \& Bujak (1994) defined five North Sea Eocene stratigraphic sequences and eight subsequences bounded by high gamma log peaks, based on the examination of over 750 released wells from Quadrant 3 to Quadrants 21 and 22. They demonstrated that each sequence and subsequence boundary consistently falls within the same dinocyst subzone, giving a high degree of confidence that these boundaries represent time lines.

Twelve dinocyst taxa used to define the zones and subzones erected by Bujak \& Mudge (1994) have not been previously described, although some have been informally illustrated from northwest Germany, Belgium and Denmark. The purpose of this paper is to formally describe these taxa in order to provide the taxonomic framework needed for the North Sea Eocene dinocyst scheme proposed by Bujak \& Mudge (1994).

\section{MATERIAL}

All of the illustrated material is from ditch cuttings, sidewall core or conventional core samples recovered from North Sea wells operated by various companies. Palynological slides containing the type material from the UK22/9-1, UK22/14-1 and UK22/16-1 wells are curated at the British Geological Survey, Keyworth. Palynological slides containing the type material from the UK15/13-2 and UK16/1a-1 wells are curated at BP Operating Company, Aberdeen. Palynological slides containing the type material from the UK21/28a-4, UK21/28a-5 and UK21/28a-6 wells are curated at Simon Petroleum Technology Limited, Llandudno. Palynological slides from all other wells were donated for curation at the Natural History Museum, London, by
Chevron UK Limited, Conoco (UK) Limited, Oryx UK Energy, Shell UK Exploration and Production, Sun International Exploration and Production, Total Oil Marine plc, and Unocal UK Limited.

\section{SYSTEMATICS}

Division Dinoflagellata (Bütschli) Fensome et al., 1993 Class Dinophyceae Pascher, 1914

Order Gronyaulacales Taylor, 1980

Family Gonyaulacaceae Lindemann, 1928 Genus Areosphaeridium Eaton, 1971

Remarks. Stover \& Williams (in press) reviewed the morphology of species that had been assigned to Areosphaeridium and emended its diagnosis, placing particular emphasis on the number and distribution of processes on the hypocyst. They distinguished two groups of species previously assigned to Areosphaeridium based on the hypocystal paratabulation. The hypocyst on Areosphaeridium diktyoplokus (Klumpp) Eaton and Areosphaeridium fenestratum Bujak typically has seven processes on paraplates $5^{\prime \prime \prime}, 1 \mathrm{p}$ and $1^{\prime \prime \prime \prime}$, arranged in the standard sexiform pattern. Stover \& Williams retained these species in Areosphaeridium, which has a confirmed stratigraphic range of late Ypresian to Priabonian, according to Stover \& Williams (in press).

Stover \& Williams (in press) erected the genus Enneadocysta to accommodate the second group of species, previously assigned to Aereosphaeridium, which have a partiform hypocystal configuration, with processes on paraplates 6"', 2"'' and 1 ps. They designated Enneadocysta pectiniformis (Gerlach) Stover \& Williams as the types species. Enneadocysta has a confirmed stratigraphic range of early Lutetian to Rupelian, according to Stover \& Williams (in press).

\section{Areosphaeridium ebdonii sp. nov.}

(Plate 2, figs 8-9)

Derivation of name. Named after the palynologist Christopher Ebdon.

Diagnosis. Cysts skolochorate with subspherical bodies comprising an autophragm. Body typically with 17 intratabular processes, ten on the epicyst and seven on the 


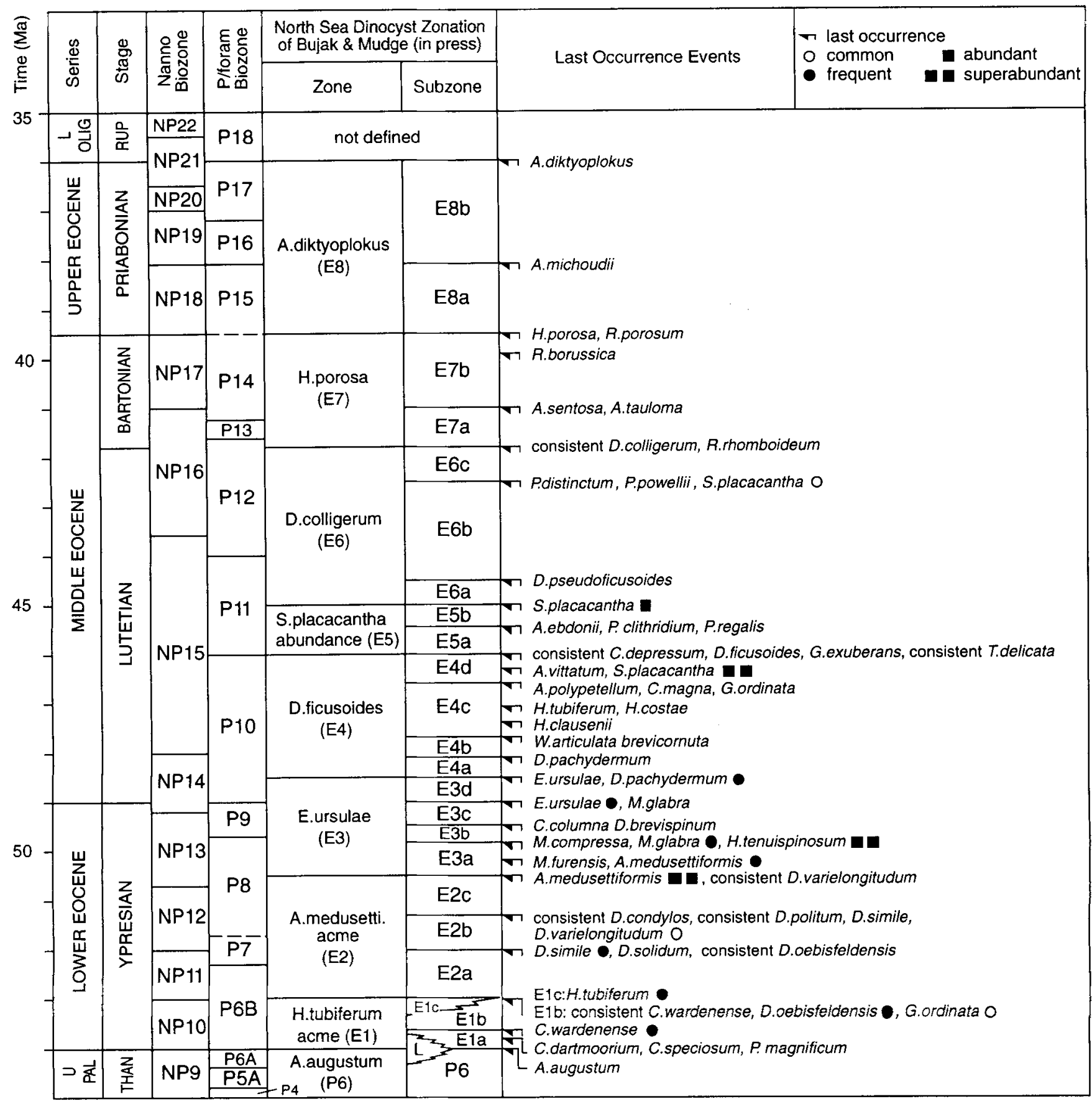

Fig. 1. The North Sea Eocene dinocyst zonation of Bujak \& Mudge (1994)

hypocyst; areas between process bases smooth, or indistinctly ornamented, or finely and irregularly granulate. Processes less than $15 \mu \mathrm{m}$ in length. Process stems solid, with proximal fibrous ends expanded slightly and merging smoothly with the autophragm surface. Process stems expanded distally into vasiform or infundibular, fenestrate to reticulate process platforms with irregular to circular outlines. On some specimens the vasiform or infundibular distal terminations have irregular or entire margins. The processes reflect a paratabulation of $4^{\prime}, 6^{\prime \prime}, 0 \mathrm{c}, 5^{\prime \prime \prime}, 1 \mathrm{p}, 1^{\prime \prime \prime \prime}$, $0 \mathrm{~s}$, with the hypocystal paratabulation following the standard sexiform pattern. Paracingulum typically expressed by the absence of processes, but one or two narrow paracingular processes may be present. Parasulcal processes absent although a medial parasutural notch is frequently discernible. Archeopyle apical; operculum tetraplacoid, contiguous.

Type locality and stratum. Locality: North Sea, UK22/14-1 
well. Stratum: section at $8020 \mathrm{ft}$, Early Eocene (Ypresian). Holotype. UK22/14-1, $8020 \mathrm{ft}$ (ditch cuttings), England Finder coordinates D44/4, illustrated in Plate 2, figs 8-9, curated at the British Geological Survey, Keyworth, slide number MPK 9725.

Paratype. UK22/14-1, $8020 \mathrm{ft}$ (ditch cuttings), England Finder coordinates U49/3, curated at the British Geological Survey, Keyworth, slide number MPK 9726.

Dimensions. Central body length (without operculum) $47-53 \mu \mathrm{m}$, breadth $40-48 \mu \mathrm{m}$, maximum process length $10-12 \mu \mathrm{m}$.

Observed stratigraphic range. North Sea dinocyst zones: E3c to E5a of Bujak \& Mudge (1994) (Early to Middle Eocene: Ypresian to Lutetian).

Remarks. A. ebdonii is distinguished from other species of Areosphaeridium by its short processes.

Areosphaeridium michoudii sp. nov.

(Plate 1, figs 1-3)

Derivation of name. Named after the palynologist Daniel Michoux.

Diagnosis. Cysts skolochorate with subspherical bodies comprising an autophragm. Central body diameter typically greater than $50 \mu \mathrm{m}$. Body typically with 17 intratabular processes, ten on the epicyst and seven on the hypocyst; areas between process bases smooth, or indistinctly ornamented, or finely and irregularly granulate. Process stems solid, with proximal fibrous ends expanded slightly and merging smoothly with the autophragm surface. Process stems expanded distally, and forming recurved or straight distal bifurcations. The distal margin of the bifurcations are digitate or bear completely or partially developed fenestrations which are restricted to a band lying along the bifurcations. The processes reflect a paratabulation of $4^{\prime}, 6^{\prime \prime}, 0 \mathrm{c}, 5^{\prime \prime \prime}, 1 \mathrm{p}, 1^{\prime \prime \prime \prime}$, $0 \mathrm{~s}$, with the hypocystal paratabulation following the standard sexiform pattern. Paracingulum typically expressed by the absence of processes. Parasulcal processes absent although a medial parasutural notch is frequently discernible. Archeopyle apical; or ro $\mathrm{r}$ um tetraplacoid, contiguous.

Type locality and stratum. Locality: North Sea, UK21/28b7 well. Stratum: section at $3900 \mathrm{ft}$, Middle Eocene (Lutetian).

Holotype. UK21/28b-7, $3900 \mathrm{ft}$ (ditch cuttings), England Finder coordinates X17/0, illustrated in Plate 1, figs 1-2, curated at The Natural History Museum, London, slide number FD 513(1).

Paratypes. UK21/28b-7, $3900 \mathrm{ft}$ (ditch cuttings), England Finder coordinates V30/3, curated at The Natural History Museum, London, slide number FD 513(3); UK16/16b-4, $6040 \mathrm{ft}$ (ditch cuttings), England Finder coordinates U39/3, curated at The Natural History Museum, London, slide number FD 524(1).

Dimensions. Central body length (without operculum) $50-58 \mu \mathrm{m}$, breadth $56-63 \mu \mathrm{m}$, maximum process length $35-40 \mu \mathrm{m}$.

Observed stratigraphic range. North Sea dinocyst zones: E2a to E8a of Bujak \& Mudge (1994) (Early to Late Eocene: Ypresian to Priabonian).
Remarks. A. michoudii is distinguished from all other species of Areosphaeridium by its distally bifid processes which lack fenestrate or reticulate process platforms. The process terminations on $A$. michoudii are similar to those on several species of Enneadocysta, including $E$. arcuata (Eaton) Stover \& Williams and E. multicornuta (Eaton) Stover \& Williams which are common in the North Sea. A. michoudii differs from all species of Enneadocysta in having a sexiform hypocystal paratabulation reflected by a processes on paraplates $5^{\prime \prime \prime}, 1 \mathrm{p}$ and $1^{\prime \prime \prime \prime}$. Species of Enneadocysta have a partiform hypocystal partabulation reflected by processes on paraplates $6^{\prime \prime}, 2^{\prime \prime \prime \prime}$ and ps.

\section{Genus Cerebrocysta Bujak in Bujak et al., 1980 Cerebrocysta magna sp. nov. (Plate 2, figs 10-11)}

Derivation of name. Latin, magnus, large, with reference to the large cyst size.

Diagnosis. Autocyst spherical to ovoidal, without apical, antapical or other projections, except for an apparently random ornament of low crests which give the cyst a cerebral appearance. The crests occasionally suggest a paratabular arrangement. Cyst diameter always exceeding $40 \mu \mathrm{m}$. Archeopyle formed by the loss of precingular paraplate $3^{\prime \prime}$.

Type locality and stratum. Locality: North Sea, UK21/28a5 well. Stratum: section at $4619 \mathrm{ft}$, Middle Eocene (Lutetian).

Holotype. UK21/28a-5, $4619 \mathrm{ft}$ (conventional core), England Finder coordinates V38/2, illustrated in Plate 2, fig. 10, curated at Simon Petroleum Technology Limited, Llandudno.

Paratypes. UK16/17-3, $6830 \mathrm{ft}$ (ditch cuttings), England Finder coordinates N47/0, curated at The Natural History Museum, London, slide number FD 514(1); UK16/26-2, $7030 \mathrm{ft}$ (ditch cuttings), England Finder coordinates F27/3, illustrated in Plate 2, fig. 11, curated at The Naturai History Museum, London, slide number FD 515(1).

Dimensions. Cyst length $49-59 \mu \mathrm{m}$, breadth $46-63 \mu \mathrm{m}$.

Observed stratigraphic range. North Sea dinocyst zones: E2c to E4c of Bujak \& Mudge (1994) (Early to Middle Eocene: Ypresian to Lutetian).

Remarks. The genus Cerebrocysta was erected by Bujak (1980) for specimens present in the Barton Beds of the Hampshire Basin, with the type species, C. bartonensis Bujak, having a cyst diameter ranging from $24-28 \mu \mathrm{m}$ (Plate 2, fig. 12). C. bartonensis is persistently present in fairly low numbers in the North Sea where it has its highest occurrence in Bartonian Subzone E7a of Bujak \& Mudge (1994). C. magna is identical to $C$. bartonensis in all respects except for its larger size, and there is no indication that the two species intergrade. C. magna has a more restricted stratigraphic range in the North Sea, having its highest occurrence at the top of Lutetian Subzone E4c of Bujak \& Mudge (1994).

Genus Diphyes Cookson, 1965 Diphyes brevispinum sp. nov. (Plate 2, figs 4-6) 

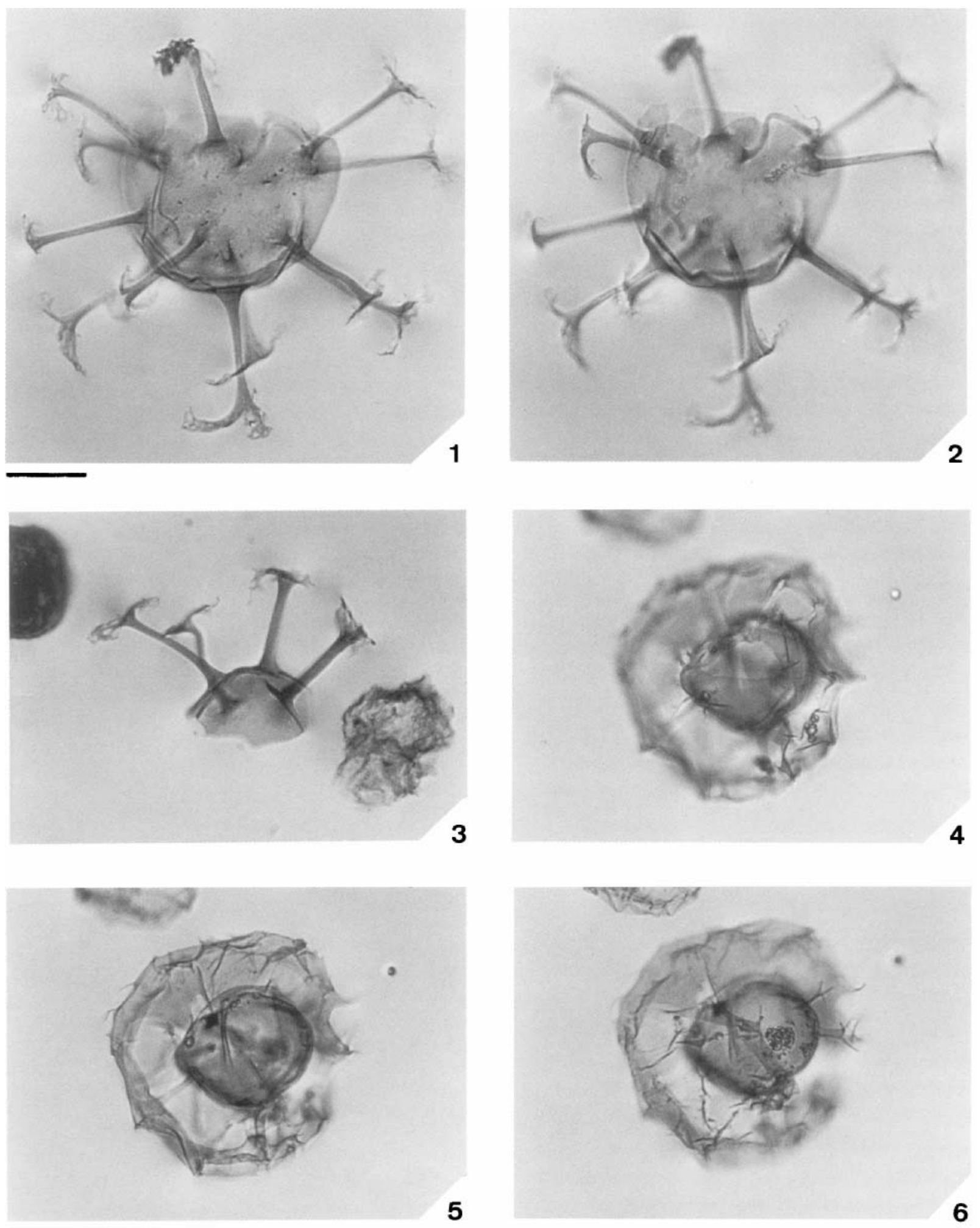

Plate 1 
Derivation of name. Latin, brevis, short, plus spina, thorn, with reference to the short processes.

Diagnosis. Cyst subspherical, skolochorate and biphragmal, endophragm and periphragm adpressed except beneath the processes. Periphragm smooth to chagrinate, forming numerous nontabular processes. Processes other than the antapical process less than $5 \mu \mathrm{m}$ in length, tubular, tapering from broader circular bases to narrow, open or closed terminations. Antapical process large, inflated, ovoidal to subspherical, with a closed circular base, and a constricted distal opening. Archeopyle apical; operculum tetraplacoid, contiguous.

Type locality and stratum. Locality: North Sea, UK21/28a4 well. Stratum: section at $4580 \mathrm{ft}$, Early Eocene (Ypresian).

Holotype. UK21/28a-4, $4580 \mathrm{ft}$ (sidewall core), England Finder coordinates R46/3, illustrated in Plate 2, figs 4-5, curated at Simon Petroleum Technology Ltd, Llandudno.

Paratypes. UK21/28a-4, $4567 \mathrm{ft}$ (sidewall core), England Finder coordinates $\mathrm{K} 38 / 0$, illustrated in Plate 2, fig. 6, curated at Simon Petroleum Technology Limited, Llandudno; UK21/28a-4, $4567 \mathrm{ft}$ (sidewall core), England Finder coordinates $\mathrm{M} 47 / 3$, curated at Simon Petroleum Technology Limited, Llandudno.

Dimensions. Central body length (without operculum) $22-28 \mu \mathrm{m}$, breadth $27-31 \mu \mathrm{m}$, antapical process length $17-20 \mu \mathrm{m}$, breadth $15-25 \mu \mathrm{m}$, maximum process length (excluding the antapical process) $2.5-4 \mu \mathrm{m}$.

Observed stratigraphic range. North Sea dinocyst zones: E3a to E3b of Bujak \& Mudge (1994) (Early Eocene: Ypresian).

Remarks. D. brevispinum is intermediate in morphology between $D$. ficusoides Islam and Duosphaeridium nudum (Cookson) Loeblich \& Loeblich. D. nudum does not possess processes except for the large antapical process, whereas $D$. ficusoides has processes that typically vary in length between $11-15 \mu \mathrm{m}$. $D$. brevispinum has a more restricted North Sea stratigraphic range than $D$. ficusoides which ranges up into Lutetian Subzone E4d of Bujak \& Mudge (1994). D. nudum is rare in North Sea wells (Bujak, pers. obs.), and has approximately the same stratigraphic range as $D$. brevispinum.

Diphyes pseudoficusoides sp. nov. (Plate 2, figs 2-3)

Derivation of name. Greek, pseudos, false, plus ficusoides, with reference to the similarity to, but distinction from Diphyes ficusoides.
Diagnosis. Cyst subspherical, skolochorate and biphragmal, endophragm and periphragm adpressed except beneath the processes. Periphragm smooth to chagrinate, forming numerous nontabular processes. Processes greater than $10 \mu \mathrm{m}$ in length; processes other than the antapical process tubular, tapering from broad circular bases to narrow necks before ending in expanded, distally aculeate or entire terminations. Antapical process expanded, having a maximum breadth of between $10 \mu \mathrm{m}$ and $15 \mu \mathrm{m}$, and tapering distally to a constricted termination that is typically open. Archeopyle apical; operculum tetraplacoid, contiguous.

Type locality and stratum. Locality: North Sea, UK15/30-4 well. Stratum: section at $5760 \mathrm{ft}$, Middle Eocene (Lutetian).

Holotype. UK $15 / 30-4,5760 \mathrm{ft}$ (ditch cuttings), England Finder coordinates L54/1, illustrated in Plate 2, fig. 3, curated at The Natural History Museum, London, slide number FD 526(1).

Paratypes. UK15/30-2, $6080 \mathrm{ft}$ (ditch cuttings), England Finder coordinates L47/2, illustrated in Plate 2, fig. 2, curated at The Natural History Museum, London, slide number FD 525(1); UK22/14-1, $7780 \mathrm{ft}$ (ditch cuttings), England Finder coordinates H39/0, curated at the British Geological Survey, Keyworth, slide number MPK 9718.

Dimensions. Central body length (without operculum) 29-34 $\mu \mathrm{m}$, breadth $27-40 \mu \mathrm{m}$, antapical process length 13-21 $\mu \mathrm{m}$, breadth $10-15 \mu \mathrm{m}$, maximum process length (excluding the antapical process) $12-17 \mu \mathrm{m}$.

Observed stratigraphic range. North Sea dinocyst zones: E2b to E6a of Bujak \& Mudge (1994) (Early to Middle Eocene: Ypresian to Lutetian).

Remarks. D. pseudoficusoides is distinguished from other species of Diphyes by its antapical process, which is intermediate in morphology between that on $D$. colligerum and $D$. ficusoides. The antapical process on $D$. colligerum typically varies in breadth between $6-8 \mu \mathrm{m}$, whereas that on $D$. ficusoides varies in breadth between $18-28 \mu \mathrm{m}$.

$D$. colligerum, $D$, pseudoficusoides and $D$. ficusoides have different stratigraphic ranges in the North Sea, where their last occurrences are zonal markers within the Eocene (Bujak \& Mudge, 1994). D. colligerum has a last consistent occurrence at the top of Subzone E6c of Bujak \& Mudge (1994), near the Lutetian-Bartonian boundary, but ranges up sporadically in the North Sea into the late Priabonian. $D$. pseudoficusoides has its last occurrence at the top of Lutetian Subzone E6a of Bujak \& Mudge (1994), and D. ficusoides has its last occurrence at the top of Lutetian

\section{Explanation of Plate 1}

Magnification bar represents $20 \mu \mathrm{m}$ for all specimens. Figs 1-3. Areosphaeridium michoudii sp. nov. Figs 1-2. Holotype. UK21/28b-7, $3900 \mathrm{ft}$, showing the sexiform hypocystal process arrangement: fig. 1, lower dorsal surface; fig. 2, upper ventral surface. Fig. 3. Isolated operculum. UK21/28b-7, $3900 \mathrm{ft}$. Figs 4-6. Hystrichostrogylon clausenii sp. nov. Holotype. UK21/28b-7, $3900 \mathrm{ft}$ : fig. 4, lower dorsal surface, showing the archeopyle formed by the loss of two precingular paraplates; fig. 5, optical section, showing the claustrum developed on the left cingular-postcingular side of the periphragm; fig. 6, upper ventral surface. 

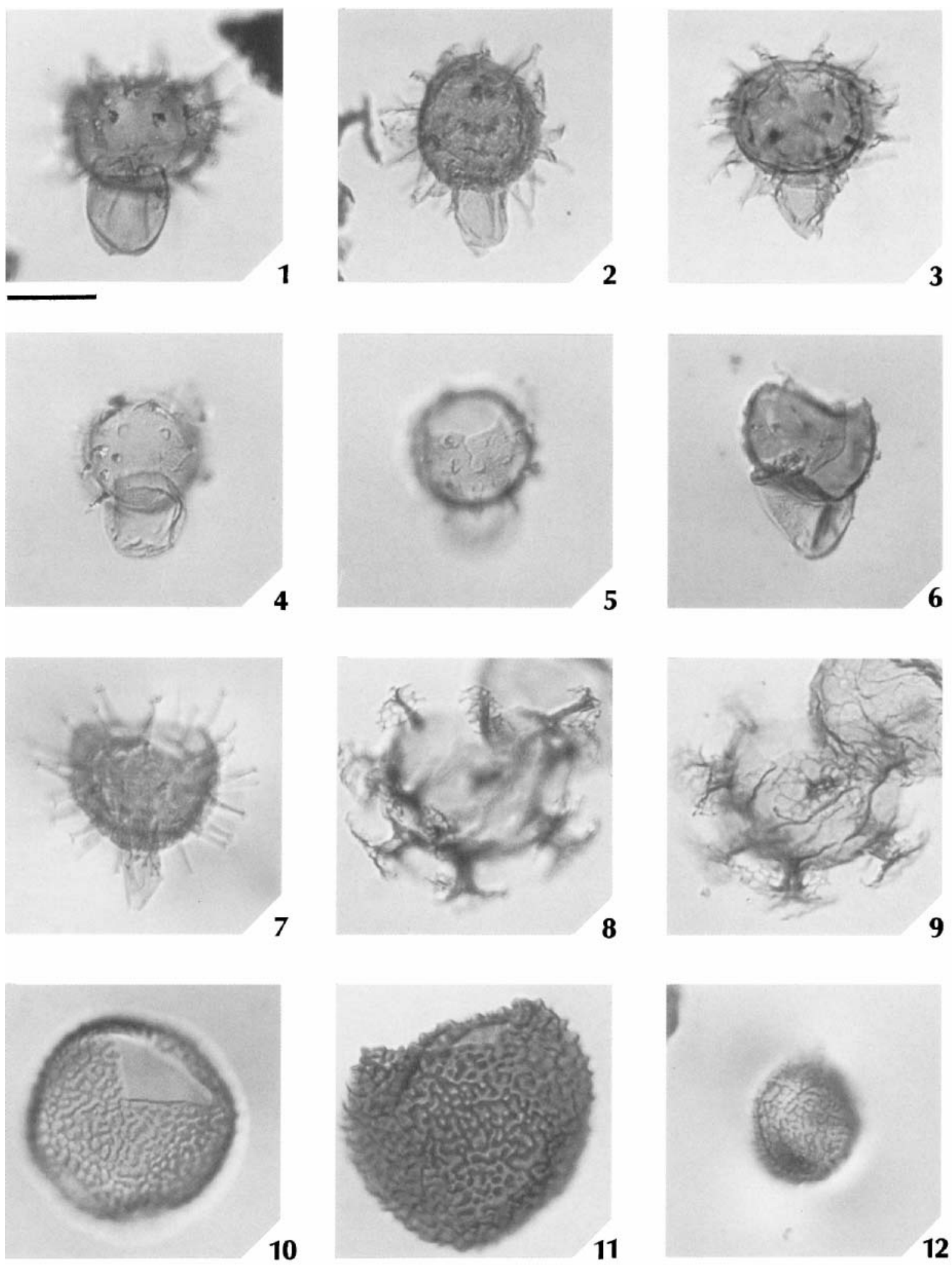

Plate 2 
Subzone E4d of Bujak \& Mudge (1994). D. ficusoides and $D$. pseudoficusoides have their first North Sea occurrences in the early Ypresian, whereas $D$. colligerum ranges down in the Palaeocene in the North Sea Basin.

\section{Genus Hystrichosphaeropsis Deflandre, 1935 Hystrichosphaeropsis costae sp. nov.}

(Plate 3, figs 1-4)

1989 Hystrichosphaeropsis sp. 1 Heilmann-Clausen \& Costa: 467 , pl. 17, figs 1-4, 6-8.

1993 Hystrichosphaeropsis sp. Heilmann-Clausen: 98, text-figs $5 \mathrm{C}-\mathrm{D}$.

Derivation of name. Named after the palynologist Lucy Costa.

Diagnosis. A species of Hystrichosphaeropsis with a weakly developed apical horn, and without antapical horns but with a well-developed antapical pericoel. Endophragm and periphragm smooth to chagrinate. Low, perforate or unperforate parasutural crests variably and incompletely developed, and typically absent from the paracingular region. Low, simple or bifid gonal processes may be present on the paracingulum. A claustrum is sometimes present near the antapex in the postcingular periphragm. Archeopyle precingular, formed by the loss of paraplate $3^{\prime \prime}$.

Type locality and stratum. Locality: North Sea, UK22/14-1 well. Stratum: section at $8020 \mathrm{ft}$, Early Eocene (Ypresian). Holotype. UK22/14-1, $8020 \mathrm{ft}$ (ditch cuttings), England Finder coordinates $\mathrm{P} 36 / 2$, illustrated in Plate 3, figs 1-3, curated at the British Geological Survey, Keyworth, slide number MPK 9719.

Paratypes. UK22/14-1, $8020 \mathrm{ft}$ (ditch cuttings), England Finder coordinates L50/1, illustrated in Plate 3, fig. 4; UK22/14-1, $8020 \mathrm{ft}$ (ditch cuttings), England Finder coordinates R64/3; UK22/14-1, $8020 \mathrm{ft}$ (ditch cuttings), England Finder coordinates M35/2; UK22/14-1, $8020 \mathrm{ft}$ (ditch cuttings), England Finder coordinates J47/4. All paratypes curated at the British Geological Survey, Keyworth, slide numbers MPK 9720 to 9723.

Dimensions. Pericyst length $56-75 \mu \mathrm{m}$, breadth $40-55 \mu \mathrm{m}$, endocyst length $32-49 \mu \mathrm{m}$, breadth $36-51 \mu \mathrm{m}$, maximum process length $3-5 \mu \mathrm{m}$.

Observed stratigraphic range. North Sea dinocyst zones: E3a to E4c of Bujak \& Mudge (1994) (Early to Middle Eocene: Ypresian to Lutetian).

Remarks. $H$. costae is distinguished from Rottnestia borussica (Eisenack) in possessing poorly developed parasutural crests, and in having processes that are absent or restricted to the paracingular region and which are much shorter than those on $R$. borussica (typical process length on $R$. borussica is greater than $10 \mu \mathrm{m}) . H$. costae differes from Hystrichosphaeropsis? rectangularis Bujak in having less well-developed parasutural crests.

$H$. costae is considered to be conspecific with Hystrichosphaeropsis sp. 1, which Heilmann-Clausen \& Costa (1989) described from the Wursterheide research well, northwest Germany, within the Glinde Formation, assigned to NP14 in their table 1. This informal species was also described from both the German Wursterheide research well and the Hinge section in Denmark as Hystrichosphaeropsis sp. by Heilmann-Clausen (1993). Heilmann-Clausen documented a morphological series from $R$. borussica to Hystrichosphaeropsis sp. and suggested that Hystrichosphaeropsis $\mathrm{sp}$. was descended from $R$. borussica.

\section{Genus Hystrichostrogylon Agelopoulos, 1964 Hystrichostrogylon clausenii sp. nov.}

(Plate 1, figs 4-6)

1989 Hystrichostrogylon sp. 1 Heilmann-Clausen \& Costa: 468 , pl. 18 , figs $5,6,8,9$.

Derivation of name. Named after the palynologist Claus Heilmann-Clausen.

Diagnosis. Endocyst smooth with a circular outline. Periphragm smooth to chagrinate, compressed dorsoventrally, forming a high membrane surrounding the ambital periphery of the cyst, except in the mid-dorsal and mid-ventral regions where the periphragm and endophram are in contact. Trifurcate and occasional bifurcate processes extend a short distance above the periphragm, except on the right lateral side of the cyst where the height of the periphragm is reduced and the length of the processes extending beyond the membrane is increased. A claustrum is typically developed on the left cingularpostcingular side of the periphragm. Archeopyle precingular, formed by the loss of paraplate $3^{\prime \prime}$ and sometimes also paraplates $2^{\prime \prime}$ and/or 4 ".

Type locality and stratum. Locality: North Sea, UK21/28b7 well. Stratum: section at $3900 \mathrm{ft}$, Middle Eocene (Lutetian).

Holotype. UK21/28b-7, $3900 \mathrm{ft}$ (ditch cuttings), England Finder coordinates G23/0, illustrated in Plate 1, figs 4-6, curated at The Natural History Museum, London, slide number FD 513(2).

Paratype. UK21/28a-6, $4320 \mathrm{ft}$ (ditch cuttings), England

\section{Explanation of Plate 2}

Magnification bar represents $20 \mu \mathrm{m}$ for all specimens. Fig. 1. Diphyes ficusoides Islam. Holotype shown for comparison with Diphyes pseudoficusoides and Diphyes brevispinum. Figs 2-3. Diphyes pseudoficusoides sp. nov.: fig. 2, paratype. UK15/30-2, 6080 ft; fig. 3, holotype. UK15/30-4, $5760 \mathrm{ft}$. Figs 4-6. Diphyes brevispinum sp. nov,: figs 4-5 Holotype. UK21/28a-4, $4580 \mathrm{ft}$; fig. 4, lower, oblique antapical view; fig. 5. upper, oblique apical view; fig. 6, paratype. UK21/28a-4, $4567 \mathrm{ft}$. Fig. 7. Diphyes colligerum (Deflandre \& Cookson) Cookson. UK21/28b-7, $3676 \mathrm{ft}$. Shown for comparison with Diphyes pseudoficusoides. Figs 8-9. Areosphaeridium ebdonii sp. nov. Holotype. UK22/14-1, 8020 ft: fig. 8, lower surface; fig. 9, upper surface. Figs 10-11. Cerebrocysta magna sp. nov.: fig. 10, holotype, lower dorsal surface. UK21/28a-5, 4619ft, fig. 11, paratype, upper surface. UK16/26-2, 7030 ft. Fig. 12. Cerebrocysta bartonensis Bujak. UK21/28b-7, $3960 \mathrm{ft}$. Shown for comparison with Cerebrocysta magna. 

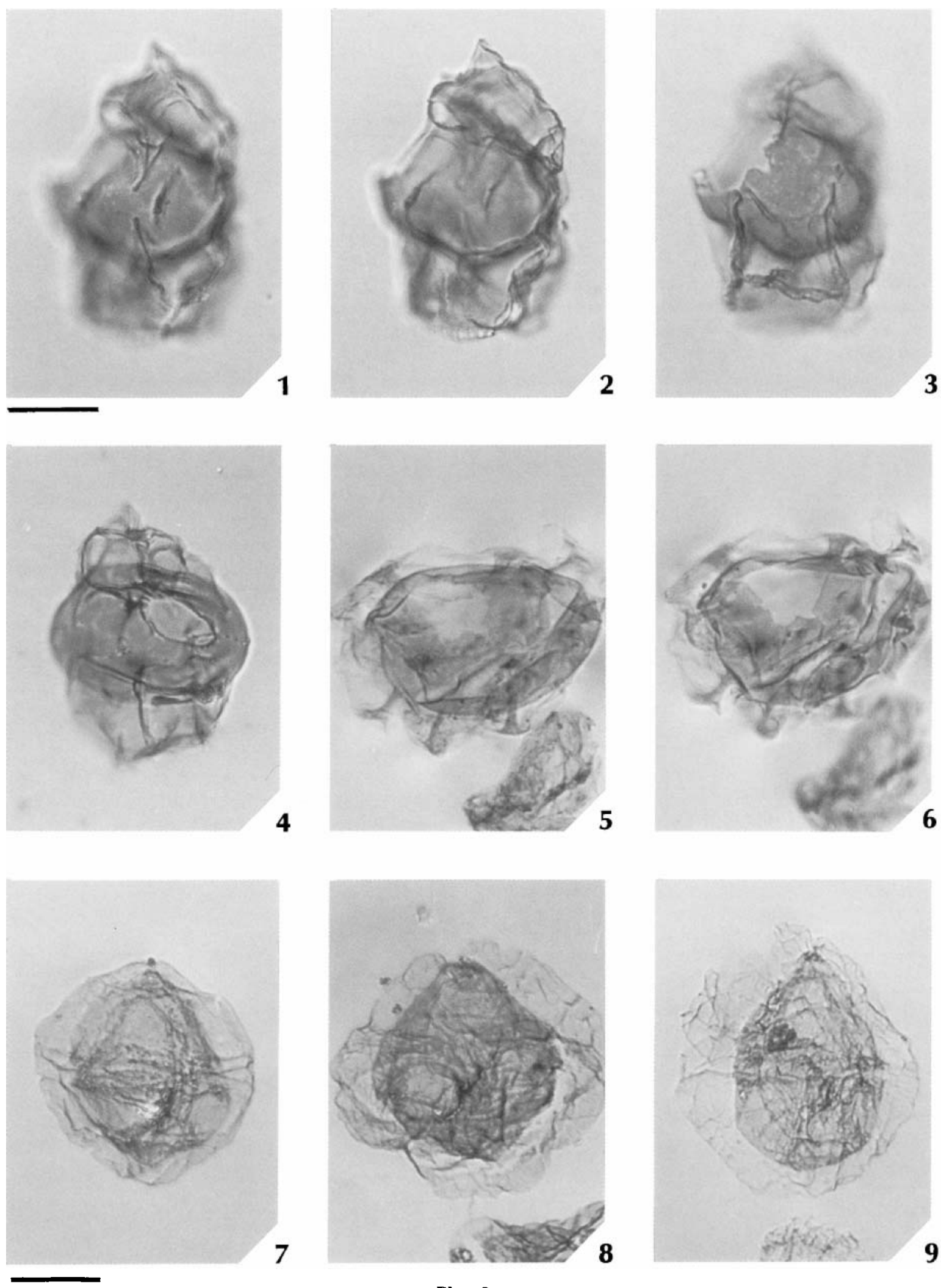

Plate 3 
Finder coordinates Q32/3, curated at Simon Petroleum Technology Limited, Llandudno.

Dimensions. Pericyst length $63-73 \mu \mathrm{m}$, breadth $63-75 \mu \mathrm{m}$, endocyst length $32-41 \mu \mathrm{m}$, breadth $31-40 \mu \mathrm{m}$.

Observed stratigraphic range. North Sea dinocyst zones: E3c to E4c of Bujak \& Mudge (1994) (Early to Middle Eocene: Ypresian to Lutetian).

Remarks. H. clausenii is considered to be conspecific with Hystrichostrogylon sp. 1, which Heilmann-Clausen \& Costa (1989) described from the Wursterheide research well, northwest Germany, within the Glinde Formation, asigned to NP14 in their table 1.

\section{Genus Membranilarnacia Eisenack, 1963 Membranilarnacia compressa sp. nov.}

(Plate 3, figs 5-6)

1975 Membranilarnacia sp. A De Coninck 1975: 94, pl. 16, figs 17-19; pl. 17, fig 1 .

1989 Membranilarnacia sp. A Heilmann-Clausen \& Costa 1989: pl. 11, figs 4, 8, 9.

Derivation of name. Latin, compressus, compressed, with reference to the compressed nature of the cyst resulting from the short processes.

Diagnosis. Endocyst subspherical to ovoidal; periphragm smooth to chagrinate, in contact with the endophragm except beneath the processes. Processes intratabular, solid or hollow, proximally and distally expanded, less than $15 \mu \mathrm{m}$ in length. Processes supporting a continuous, smooth, entire, or occasionally perforate ectophragm. Paratabulation gonyaulacoid, delimited formula $4^{\prime}, 66^{\prime \prime}, 0 \mathrm{c}$, $5^{\prime \prime \prime}, \quad$ lp, 1'"', 0s. Archeopyle apical; tetraplacoid and contiguous.

Type locality and stratum. Locality: North Sea, UK21/28b7 well. Stratum: section at $3960 \mathrm{ft}$, Early Eocene (Ypresian).

Holotype. UK21/28b-7, $3960 \mathrm{ft}$, (ditch cuttings) England Finder coordinates M34/4, illustrated in Plate 3, figs 5-6, curated at The Natural History Museum, London, slide number FD 516(1).

Paratype. UK21/28b-7, $3960 \mathrm{ft}$, (ditch cuttings) England Finder coordinates N23/2, curated at The Natural History Museum, London, slide number FD 516(2).

Dimensions. Central body length (without operculum) $37-50 \mu \mathrm{m}$, breadth $36-52 \mu \mathrm{m}$, maximum process length 6-11 $\mu \mathrm{m}$.

Observed stratigraphic range. North Sea dinocyst zones: E2a to E3a of Bujak \& Mudge (1994) (Early Eocene: Ypresian).

Remarks. The ectophragm on $M$. compressa is generally entire, but rare specimens have been observed in the
North Sea with a perforate ectophragm. These have the same stratigraphic range as specimens with an entire ectophragm, and they are included in $M$. compressa.

$M$. compressa has shorter processes than those on Membranilarnacia glabra Agelopoulos, which are typically $15-21 \mu \mathrm{m}$ in length $M$. glabra last occurs in the North Sea at the top of Ypresian Subzone E3c of Bujak \& Mudge (1994), whereas $M$. compressa last occurs at the top of Ypresian Subzone E3a of Bujak \& Mudge (1994). Species of Eatonicysta Stover \& Evitt differ from $M$. compressa in possessing an ectophragm that is reticulate, fenestrate or irregularly net-like.

$M$. compressa is considered to be conspecific with Membranilarnacia sp. A, which De Coninck (1975) illustrated from the Argile de Merelbeke in the Kallo borehole, Belgium, assigned to NP13 by Verbeek (1988). Heilmann-Clausen \& Costa (1989) also recorded Membranilarnacia sp. A sensu De Coninck (1975) from the Ypresian Heiligen-Hafen Formation of the Wursterheide research well, northwest Germany, between sections assigned to NP12 and NP14.

Family Deflandreaceae Eisenack, 1954

Genus Phthanoperidinium Drugg \& Loeblich, 1967

Remarks. Islam (1982) emended the diagnosis of Phthanoperidinium to include three major types of archeopyle: (1) intercalary archeopyles involving paraplate 2a; (2) combination precingular-intercalary archeopyles involving paraplates 4" and 2a; (3) combination precingular-intercalary archeopyles involving paraplates $2-4 "$ and 1-3a.

Phthanoperidinium clithridium sp. nov.

(Plate 4, figs 1-3)

Derivation of name. Greek, kleithridion, small key-hole, with reference to the shape of the archeopyle.

Diagnosis. Pericyst ovoidal with one small apical horn and one or two unequal antapical horns, the right always being strongly reduced. Endocyst ovoidal, and in contact with the periphragm except sometimes beneath the apical and antapical horns. Periphragm chagrinate to granulate with or without extremely low parasutural crests. When present these partially delimit a paratabulation of $4^{\prime}, 3 a, 7^{\prime \prime}, x c$, $5^{\prime \prime \prime}, 2^{\prime \prime \prime}$. An archeopyle is always formed by the loss of paraplates $2 \mathrm{a}$ and $4 "$.

Type locality and stratum. Locality: North Sea, UK16/16b4 well. Stratum: section at $5900 \mathrm{ft}$, Middle Eocene (Lutetian).

Holotype. UK16/16b-4, $5900 \mathrm{ft}$ (ditch cuttings), England Finder coordinates K36/4, illustrated in Plate 4, figs 1-2,

Magnification bar represents $20 \mu \mathrm{m}$ for all specimens. Figs 1-4: Hystrichosphaeropsis costae sp. nov. Figs 1-3. Holotype. UK22/14-1, 8020 ft: fig. 1, lower surface; fig. 2, optical section; fig. 3, upper surface. Fig. 4. Paratype. UK22/14-1, 8020 ft. Figs 5-6. Membranilarnacia compressa sp. nov. Holotype. UK21/28b-7, $3960 \mathrm{ft}$; fig. 5, lower surface; fig. 6, upper surface. Figs 7-9. Phthanoperidinium powellii sp. nov.: fig. 7, paratype. UK16/16b-4, $5200 \mathrm{ft}$; figs 8 , holotype. UK16/26-2, $6280 \mathrm{ft}$; fig. 9, paratype. UK16/17-2A, $6010 \mathrm{ft}$. 

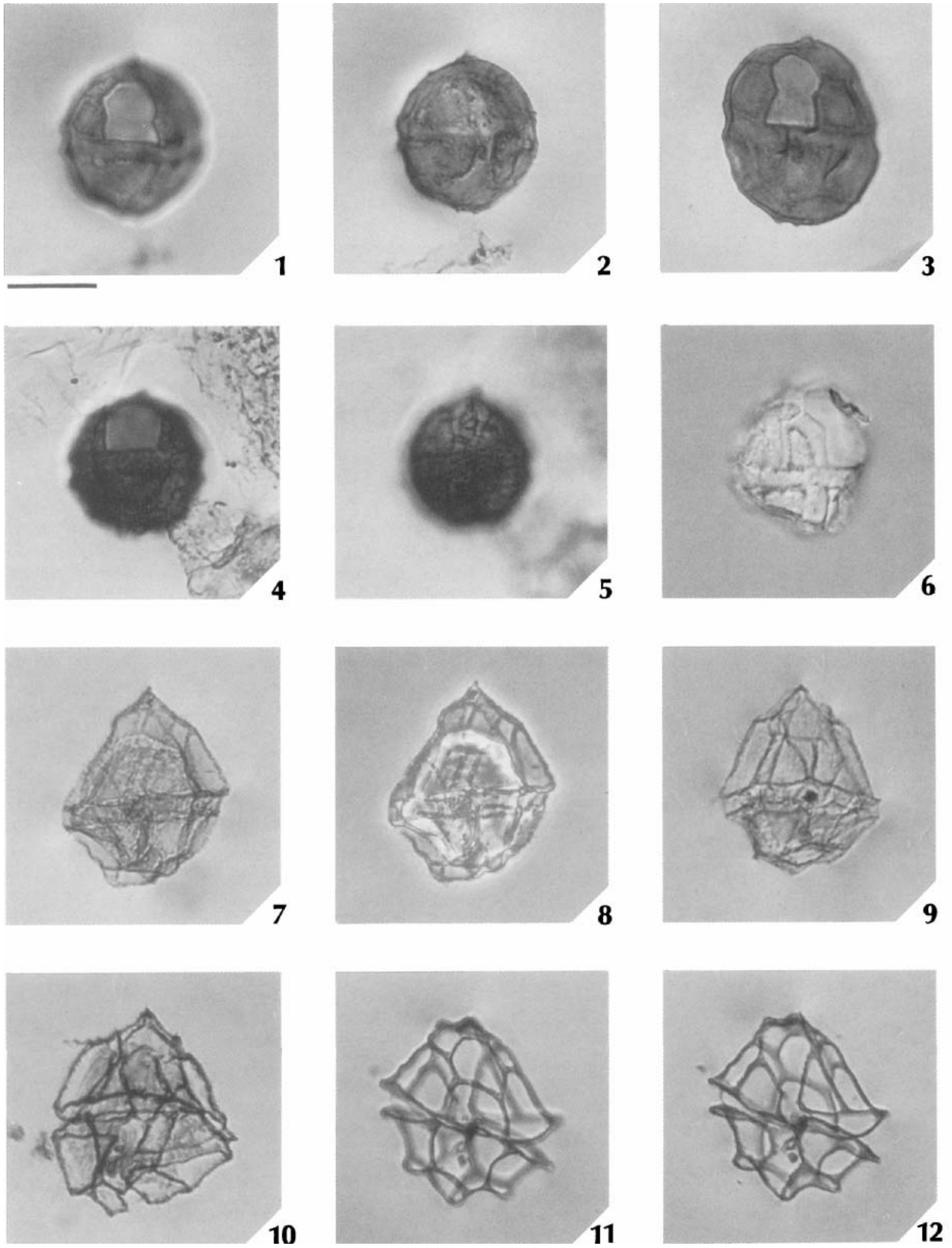

Plate 4 
curated at The Natural History Museum, London, slide number FD 518(1).

Paratypes. UK16/16b-4, $5900 \mathrm{ft}$ (ditch cuttings), England Finder coordinates P35/2, illustrated in Plate 4, fig. 3, curated at The Natural History Museum, London, slide number FD 518(2); UK16/16b-4, $6040 \mathrm{ft}$ (ditch cuttings), England Finder coordinates P41/0, curated at The Natural History Museum, London, slide number FD 525(1).

Dimensions. Pericyst length $32-44 \mu \mathrm{m}$, breadth $27-40 \mu \mathrm{m}$, apical horn length less than $2 \mu \mathrm{m}$.

Observed stratigraphic range. North Sea dinocyst zones: E4c to E5a of Bujak \& Mudge (1994) (Middle Eocene: Lutetian).

Remarks. $P$. clithridium is distinguished from all other species of Phthanoperidinium except $P$. regalis by the formation of an archeopyle involving the loss of paraplates $2 \mathrm{a}$ and $4^{\prime \prime}$. The mode of archeopyle formation is identical in $P$. clithridium and $P$. regalis which differ in their ornament. $P$. clithridium does not possess the penitabular ornament present on $P$. regalis and has less well-defined parasutural ornament. Rare specimens intergrade between these taxa, but the majority of specimens comprise distinct morphological populations, which have different palaeogeographic distributions in the North Sea (Bujak, pers. obs.). $P$. clithridium has not been recorded outside the North Sea region.

Phthanoperidinium distinctum sp. nov.

(Plate 4, figs 7-12)

Derivation of name. Latin, distinctus, distinct, with reference to the distinctive morphology of the cyst.

Diagnosis. Pericyst subpolygonal peridinioid, with a small but distinct apical horn, without antapical horns or with a poorly developed left antapical horn. Endocyst ovoidal, thin and often corroded, sometimes absent due to preservation, exhibiting birefringence under phase contrast illumination. Periphragm thin and chagrinate, forming low but thick and robust parasutural crests that are distally smooth and delimit a paratabulation of $4^{\prime}, 3 \mathrm{a}, 7^{\prime \prime}, 6 \mathrm{c}, 5^{\prime \prime \prime}$, $2^{\prime \prime \prime \prime}$. Penitabular areas of the periphragm between the parasutural crests may be absent due to corrosion. Archeopyle formed by the loss of paraplate $2 \mathrm{a}$.

Type locality and stratum. Locality: North Sea, UK16/16b4 well. Stratum: section at $5624 \mathrm{ft}$, Middle Eocene (Lutetian).

Holotype. UK16/16b-4, $5624 \mathrm{ft}$ (sidewall core), England Finder coordinates K24/3, illustrated in Plate 4, figs 7-8, curated at The Natural History Museum, London, slide number FD 519(1).
Paratypes. UK21/28a-5, $4460 \mathrm{ft}$ (ditch cuttings), England Finder coordinates E39/2, illustrated in Plate 4, fig. 9, curated at Simon Petroleum Technology Limited, Llandudno; UK21/28b-7, $3740 \mathrm{ft}$ (ditch cuttings), England Finder coordinates N35/2, curated at The Natural History Museum, London, slide number FD 520(1).

Dimensions. Pericyst length $37-50 \mu \mathrm{m}$, breadth $38-46 \mu \mathrm{m}$, apical horn length less than $2 \mu \mathrm{m}$.

Observed stratigraphic range. North Sea dinocyst zones: E6a to E6b of Bujak \& Mudge (1994) (Middle Eocene: Lutetian).

Remarks. $P$. distinctum is characterized by its peridinioid shape, thin birefringent endocyst that may be corroded or absent, and the low but robust smooth parasutural crests. The periphragm between the crests is thin and may be absent, so that all that remains of the cyst in these extreme cases is a paratabular network of crests (Plate 4, figs 11-12).

Phthanoperidinium powellii sp. nov.

(Plate 3, figs 7-9)

Derivation of name. Named after the palynologist A.J. Powell.

Diagnosis. Endocyst compressed dorso-ventrally, with an oval ambitus and one small conical apical horn; antapical horns absent or very poorly developed. Endophragm relatively thick, ovoidal and chagrinate to granulate. Pericyst ovoidal, sometimes with a small, solid apical horn. Periphragm thin and smooth to chagrinate, separated from the endocyst by a wide pericoel. Paratabulation indistinct or absent, sometimes poorly delimited by extremely low and indistinct parasutural crests on the periphragm. Paracingulum circular to weakly helicoidal, delimited by low crests. Parasulcus narrow and poorly defined. Archeopyle typically formed by the loss of paraplate $2 \mathrm{a}$, or by the loss of paraplates $1 \mathrm{a}$ to $3 \mathrm{a}$ on rare specimens.

Type locality and stratum. Locality: North Sea, UK16/26-2 well. Stratum: section at $6280 \mathrm{ft}$, Middle Eocene (Lutetian).

Holotype. UK16/26-2, $6280 \mathrm{ft}$ (ditch cuttings), England Finder coordinates P34/1, illustrated in Plate 3, fig. 8, curated at The Natural History Museum, London, slide number FD 521(1).

Paratypes. UK16/16b-4, $5200 \mathrm{ft}$ (ditch cuttings), England Finder coordinates $\mathrm{N} 28 / 0$, illustrated in Plate 3 , fig. 7 , curated at The Natural History Museum, London, slide number FD 522(1); UK16/17-2A, $6010 \mathrm{ft}$, England Finder coordinates $\mathrm{U} 36 / 3$, illustrated in Plate 3 , fig. 9, curated at The Natural History Museum, London, slide number FD $523(1)$.

\section{Explanation of Plate 4}

Magnification bar represents $20 \mu \mathrm{m}$ for all specimens. Figs 1-3. Phthanoperidinium clithridium sp. nov. Figs. 1-2. Holotype. UK16/16b-4, $5900 \mathrm{ft}$ : fig. 1, lower dorsal surface showing the archeopyle formed by the loss of paraplates $4^{\prime \prime \prime}$ and $2 \mathrm{a}$; fig. 2, upper ventral surface. Fig. 3. paratype. UK16/16b-4, $5900 \mathrm{ft}$. Figs 4-6. Phthanoperidinium regalis sp. nov. Figs 4-5. Holotype. UK16/16b-4, 6040 ft: fig. 4, upper dorsal surface; fig. 5, optical section. Fig. 6. Paratype. 16/16a-3, $1689 \mathrm{~m}$. Figs 7-12. Phthanoperidinium distinctum sp. nov. Figs 7-8. Holotype. UK16/16b-4, $5624 \mathrm{ft}$ : fig. 8, phase contrast illumination showing the birefringent endocyst. Fig. 9. Paratype. UK21/28a-5, 4460 ft. Fig. 10. UK22/16-1, $8100 \mathrm{ft}$. Specimen with a corroded endophragm. Figs 11-12. UK21/28a-4, $4190 \mathrm{ft}$. Specimen without endophragm, and with the periphragm removed between the paratabular crests: fig. 11, lower dorsal surface; fig. 12, upper ventral surface. 
Dimensions. Pericyst length $56-65 \mu \mathrm{m}$, breadth $51-65 \mu \mathrm{m}$, endocyst length $43-51 \mu \mathrm{m}$, breadth $34-44 \mu \mathrm{m}$, maximum pericoel height $7.5-14 \mu \mathrm{m}$, apical horn length on endocyst 3-5 $\mu \mathrm{m}$.

Observed stratigraphic range. North Sea dinocyst zones: E6a to E6b of Bujak \& Mudge (1994) (Middle Eocene: Lutetian).

Remarks. $P$. powelli is distinguished from all other species of Phthanoperidinium by the presence of a large pericoel.

Phthanoperidinium regalis $\mathrm{sp}$. nov.

(Plate 4, figs 4-6)

Derivation of name. Latin, regale, royal.

Diagnosis. Pericyst ovoidal with one small apical horn and one or two unequal antapical horns, the right always being strongly reduced. An endocyst is rarely visible, but is sometimes present beneath the apical horn. Periphragm chagrinate to granulate with parasutural rows of granulae, short spines, or low, irregular crests. These delimit a paratabulation of $4^{\prime}, 3 \mathrm{a}, 7^{\prime \prime}, 6 \mathrm{c}, 5^{\prime \prime \prime}, 2^{\prime \prime \prime \prime}$. Strongly developed penitabular rows or zones of similar ornament lie $1-3 \mu \mathrm{m}$ inside the parasutures, except adjacent to the paracingulum where the parasutural and penitabular ornament merges. Archeopyle always formed by the loss of paraplates $2 \mathrm{a}$ and $4 "$.

Type locality and stratum. Locality: North Sea, UK16/16b4 well. Stratum: section at $6040 \mathrm{ft}$, Middle Eocene (Lutetian).

Holotype. UK16/16b-4, $6040 \mathrm{ft}$ (ditch cuttings), England Finder coordinates K26/4, illustrated in Plate 4, figs 4-5, curated at The Natural History Museum, London, slide number FD 525(2).

Paratype. UK16/16a-3, $1689 \mathrm{~m}$ (sidewall core), England Finder coordinates P37/1, illustrated in Plate 4, fig. 6, curated at BP Operating Company, Aberdeen.

Dimensions. Pericyst length 37-46 $\mu \mathrm{m}$, breadth $33-37 \mu \mathrm{m}$, apical horn length $2-3 \mu \mathrm{m}$.

Observed stratigraphic range. North Sea dinocyst zones: E4c to E5a of Bujak \& Mudge (1994) (Middle Eocene: Lutetian).

Remarks. $P$. regalis is identical to $P$. geminatum Bujak in all respects except for the mode of archeopyle formation which comprises the loss of paraplate $2 \mathrm{a}$ in $P$. geminatum, and the loss of paraplates $2 \mathrm{a}$ and $4^{\prime \prime}$ in $P$. regalis. The stratigraphic ranges of the two taxa are also distinct. $P$. regalis has its last North Sea occurrence in Lutetian Subzone E5a of Bujak \& Mudge (1994), whereas P. geminatum ranges up into the Bartonian.

The mode of archeopyle formation is identical in $P$. regalis and $P$. clithridium which differ in their ornament. $P$. clithridium does not possess the penitabular ornament present on $P$. regalis and has less well-defined parasutural crests. Rare specimens intergrade between these taxa, but the majority of specimens assigned to the two taxa comprise populations with distinct palaeogeographic distributions in the North Sea (Bujak, pers. obs.). P. regalis has not been recorded outside the North Sea region.

\section{ACKNOWLEDGEMENTS}

The author is grateful to $\mathrm{H}$. Brinkhuis, J. De Coninck and C. Heilmann-Clausen for their constructive comments on the manuscript. Thanks are also due to the following for permission to use palynological slides as reference material for type specimens: the British Geological Survey, BP Operating Company, Chevron UK Limited, Conoco (UK) Limited, Mobil North Sea Limited, Oryx UK Energy Company, Shell UK Exploration and Production, Simon Petroleum Technology Limited, Sun International Exploration and Production, Total Oil Marine plc, and Unocal UK Limited.

\section{Manuscript received June 1993 \\ Manuscript accepted December 1993}

\section{REFERENCES}

Agelopoulos, J. 1964. Hystrichostrogylon membraniphorum n.g. n.sp. aus dem Heiligenhafener Kieselton (Eozän). Neues Jahrbuch fiur Geologie und Paläontologie, Monatshefte, 673-675.

Bujak, J. P. 1980. Dinoflagellate cysts and acritarchs from the Eocene Barton Beds of southern England. In Bujak, J. P., Downie, C., Eaton G. L. \& Williams, G. L. (Eds) Dinoflagellate cysts and acritarchs from the Eocene of southern England, 36-91, The Palaeontological Association, Special Papers in Palaeontology, 24.

Bujak, J. P. Downie, C., Eaton, G. L. \& Williams, G. L. 1980. Dinoflagellate cysts and acritarchs from the Eocene of southern England. The Palaeontological Association, Special Papers in Palaeontology, 24.

Bujak, J. P. \& Mudge, D. C. 1994. A high-resolution North Sea Eocene dinocyst zonation. Journal of the Geological Society, London, 151: 449-462.

Cookson, I. C. 1965. Microplankton from the Browns Creek Clays, SW Victoria. Proceedings of the Royal Society of Victoria, 79: 119-131.

De Coninck, J. 1975. Microfossiles à paroi organique de l'Yprésien du Bassin belge. Ministère des affaires economiques. Service Géologique de Belgique, Prof. Paper no. 12 (1975), 1-151.

Deflandre, G. 1935. Considérations biologiques sur les microorganismes d'origine planctonique conservés dans les silex de la craie. Bulletin biologique de la France et de la Belgique, 69: 213-244.

Drugg, W. S. \& Loeblich, A. R., Jr. 1967. Some Eocene and Oligocene phytoplankton from the Gulf Coast, U.S.A. Tulane Studies in Geology, 5: 181-194.

Eaton, G. L. 1971. A morphogenetic series of dinoflagellate cysts from the Bracklesham Beds of the Isle of Wight, southern England. In Farinacci, A (Ed.), Proceedings of the Second Planktonic Conference Rome 1970, 1: 355-379, Edizioni Technoscienza, Rome.

Eisenack, A. 1954. Mikrofossilien aus Phosphoriten des samländischen Ünteroligozäns und über die Einheitlichkeit der Hystrichosphaerideen. Palaeontographica, Abt. A, 105: 49-95.

Eisenack, A. 1963. Zur Membranilarnax-Frage. Neues Jahrbuch für Geologie und Paläontologie, Monatshefte, 98-103.

Fensome, R. A., Taylor, F. J. R., Norris, G., Sarjeant, W. A. S., Wharton, D. I. \& Williams, G. L. 1993. A classification of living and fossil dinoflagellates. Micropaleontology Press, Special Publication, 7, 1-351.

Heilmann-Clausen, C. 1993. Gradual morphological changes in some dinoflagellate cysts from the Eocene (Lower Tertiary) of the North Sea Basin. Palynology, 17: 91-100.

Heilmann-Clausen, C. \& Costa, L. I. 1989. Dinoflagellate zonation of the uppermost Paleocene? to Lower Miocene in the Wursterheide research well, NW Germany. Geologisches Jahrbuch, A111: 431-521. 
Islam, M. A. 1982. Archeopyle structure in the fossil dinoflagellate Phthanoperidinium. Review of Palaeobotany and Palynology, 36: 305-316.

Lejeune-Carpentier, M. 1938. L'étude microscopique des silex. Areoligera: nouveau genre d'Hystrichosphaeridée (Sixiéme note). Annales de la Société géologique de Belgique, 62: B163-B174.

Lindemann, E. 1928. Abteilung Peridineae (Dinoflagellatae). In Engler, A. \& Prantl, K (Eds), Die Natïrlichen Pflanzenfamilien nebst ihren Gattungen und wichtigeren Arten insbesondere den Nutzflanzen. Zweite stark vermehrte und verbesserte Auflage herausgegeben von A. Engler. 2 Band, 3-104. Wilhelm Engelmann, Leipzig.

Mudge, D. C. \& Bujak, J. P. 1994. Eocene stratigraphy of the North Sea basin. Journal of Sedimentary and Petroleum Geology, 11: $166-181$.

Pascher, A. 1914. Über Flagellaten und Algen. Deutsche Botanische
Gesellachaft, Berichte, 32: 136-160.

Stover, L. E. \& Evitt, W. R. 1978. Analyses of pre-Pleistocene organic-walled dinoflagellates. Stanford University Publications, Geological Sciences, 15.

Stover, L. E. \& Williams, G. L. in press Morphology and stratigraphy of the Paleogene dinoflagellate genera Areosphaeridium Eaton 1971 and Eatonicysta Stover and Evitt 1978. Micropaleontology.

Taylor, F. J. R. 1980. On Dinoflagellate Evolution. Biosystems, 13: 65-108.

Verbeek, J. W. 1988 The regional distribution of nannoplankton assemblages; correlation of the interregional zonation with the regional lithostratigraphic formations. The Netherlands. In Verbeek, R. (Comp.), The Northwest European Tertiary Basin, 273-275. Results of the International Geological Correlation Programme, Project No. 124. Geologisches Jahrbuch, A, 100. 